\title{
Núcleos de Significação como Instrumento para a Apreensão da Constituição dos Sentidos
}

The meaning core as an instrument for the understanding of the sense constitution

Wanda Maria Junqueira Aguiar \& Sergio Ozella

Pontifícia Universidade Católica de São Paulo

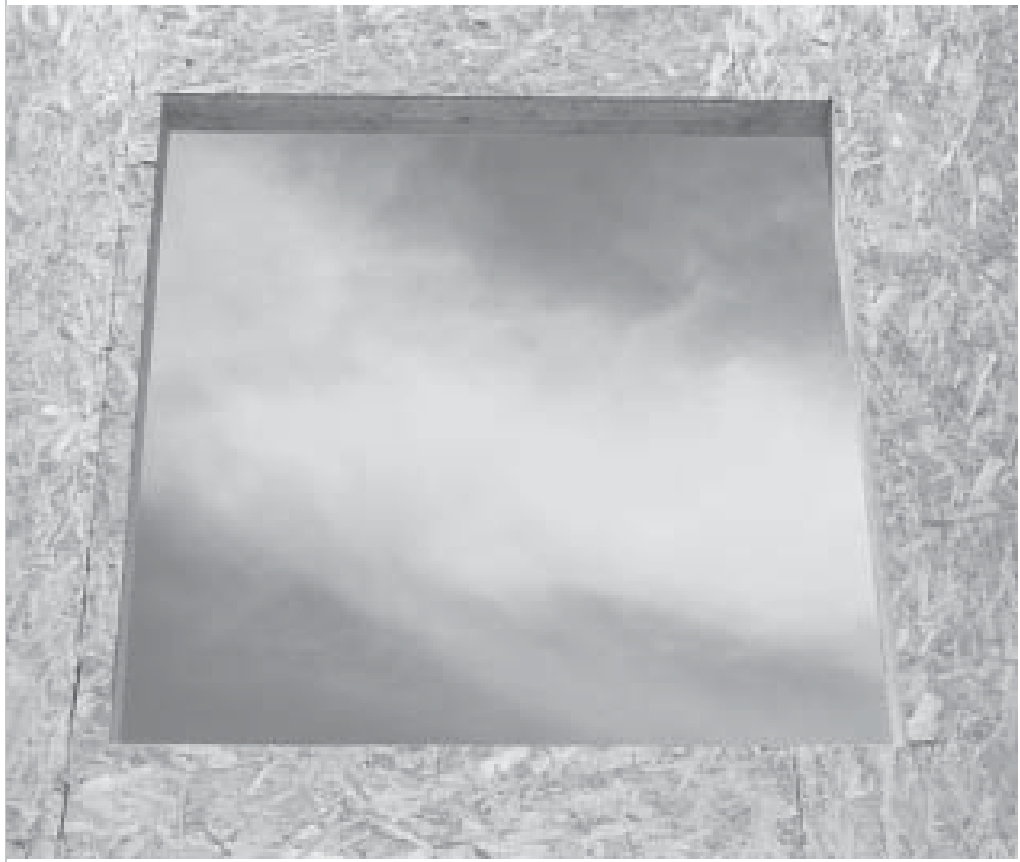




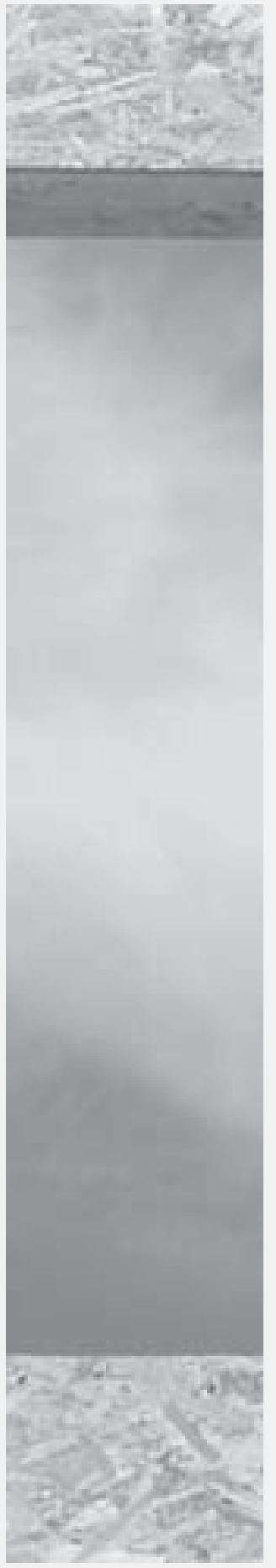

Resumo: $\mathrm{O}$ artigo tem como objetivo instrumentalizar o pesquisador, segundo a abordagem da Psicologia sociohistórica, nos procedimentos de análise de material qualitativo, visando a apreender os sentidos que constituem o conteúdo do discurso dos sujeitos informantes através do que chamamos de núcleos de significação. Na primeira parte, é feita uma retomada de aspectos teórico-metodológicos desenvolvidos a partir, basicamente, de Vigotski, tais como a importância de um método materialista histórico e dialético, as categorias linguagem e pensamento e as noções de significado e sentido, necessidades e motivos. Na segunda parte, propomos algumas etapas de procedimento de organização e análise do material levantado, particularmente através de entrevistas, visando a chegar aos núcleos de significação no caminho da apreensão dos sentidos e da subjetividade dos informantes. Destacamos três etapas: préindicadores, indicadores e núcleos de significação. Complementando o texto, ilustramos os procedimentos propostos com uma dissertação de mestrado e uma tese de doutorado orientadas pelos autores, no sentido de visualizar a análise dos núcleos de significação.

Palavras-chave: Psicologia sociohistórica, metodologia, sentidos, núcleo de significação.

\begin{abstract}
.Abstract:The main objective of this article is to give the researchers tools, using the sociohistoric psychological view, in the analyses procedure of the qualitative material, aiming to learn the sense that constitutes the speech content of the subject informant, through what we call the meaning core. In the first part, a retake of the theoretical methodological aspects developed basically by Vigotski is done, such as the importance of the historical and dialectical materialism method, the language and thought category and the notions of meaning and sense, necessities and goals. In the second part, we propose some stages of procedures to organize and analyze the collected material, mainly through the interviews, aiming to get in the core of the meaning in order to learn the sense and the subjective quality of the informants. We point out three stages: pre - indicators, indicators and meaning core. To complete the text, we illustrated the proposals procedure with a master dissertation and a Phd thesis orientated by the authors as a way to visualize the analysis of the meaning core.
\end{abstract}

Key words: sociohistoric Psychology, methodology, sense, meaning core. 
Para iniciarmos nossa discussão sobre a categoria sentido e suas implicações metodológicas, torna-se necessário, inicialmente, que se destaque, mesmo que brevemente, alguns aspectos teóricometodológicos desenvolvidos especialmente por Vigotski, como : a importância de um método materialista dialético, as categorias linguagem e pensamento e as noções de significado e sentido.

Desde 1927, quando escreve O Significado Histórico da Crise da Psicologia - uma Investigação Metodológica, Vigotski destaca a importância de um método que desse conta da complexidade do que entendia como objeto da Psicologia, ou seja, o Homem e suas funções psicológicas. Fica evidente que a Psicologia seria impotente para superar as tarefas práticas que se lhe apresentavam se não contasse com uma infra-estrutura lógicometodológica própria. Revela-se, dessa forma, nas reflexões do autor, a necessidade de uma teoria que fizesse a mediação entre o método materialista histórico e os fenômenos psíquicos. Vejamos: ainda nesse texto, o autor afirma ter a clareza de que não padece de mania de grandeza, pensando que a história começa com ele, mas tem a pretensão de realizar a Psicologia como ciência. A ciência, nessa perspectiva, deve ter como pedra angular a idéia da inseparabilidade do lógico, da base material, da dialética e do histórico. Dessa forma, concordamos com Vigotski quando este afirma que a tarefa daqueles que pretendem aplicar o marxismo à ciência deve ser a de elaborar um método, "...um sistema de procedimentos mediadores concretos de organização dos conhecimentos que podem ser aplicados precisamente à escala dessa ciência......A dialética ( metodologia) é chamada a reproduzir, no plano do cognitivo, a dialética objetiva do psiquismo (1996, p.471).

Sem a intenção de nos determos na análise dos aspectos que definem tal método, destacamos, como decorrência da adoção dessa perspectiva metodológica, a crítica radical das visões reducionistas, objetivistas e subjetivistas, ${ }^{1}$ a discussão sobre a relação aparência - essência, parte - todo, a importância da noção de historicidade, de processo e a noção de mediação. ${ }^{2}$

Desse modo, frisamos que nossa reflexão metodológica sobre a apreensão dos sentidos estará pautada numa visão que tem no empírico seu ponto de partida, mas a clareza de que é necessário irmos além das aparências, não nos contentarmos com a descrição dos fatos, mas buscarmos a explicação do processo de constituição do objeto estudado, ou seja, estudá-lo no seu processo histórico. No entanto, ao nos referirmos aos pontos essenciais a serem considerados sobre o método, não podemos deixar de mencionar a impossibilidade de se construir um método alheio a uma concepção de homem. Assim, falamos de um homem constituído numa relação dialética com o social e com a História, sendo, ao mesmo tempo, único, singular e histórico. Esse homem, constituído na e pela atividade, ao produzir sua forma humana de existência, revela - em todas as suas expressões -, a historicidade social, a ideologia, as relações sociais, o modo de produção. Ao mesmo tempo, esse mesmo homem expressa a sua singularidade, o novo que é capaz de produzir, os significados sociais e os sentidos subjetivos. Indivíduo e sociedade vivem uma relação na qual se incluem e se excluem ao mesmo tempo. Quando afirmamos se incluem, lembramos Vigotski (2001), quando afirma que o indivíduo é "quase o social"; para ele, não há invenções individuais no sentido estrito da palavra. Em todas, existe sempre alguma colaboração anônima. E, quando afirmamos se excluem, se diferenciam, destacamos a singularidade do sujeito. Entendemos, dessa forma, que indivíduo e sociedade não mantêm uma relação isomórfica entre si, mas uma relação onde um constitui o outro. Concordamos quando Vigotski (1999) afirma que o Processo de Internalização deveria ser 
chamado de "Processo de Revolução", pressupondo uma radical reestruturação da atividade psíquica nesse movimento chamado de Internalização.

Ainda nos detendo na questão metodológica, vemos a necessidade de apresentar uma breve discussão sobre a categoria mediação, dada sua importância para a perspectiva adotada. O uso dessa categoria nos permite romper as dicotomias interno-externo, objetivo-subjetivo, significado-sentido, assim como afastar-nos das visões naturalizantes, baseadas numa concepção de homem fundada na existência de uma essência metafísica. Por outro lado, possibilita-nos uma análise das determinações inseridas num processo dialético, portanto, não causal, linear e imediato, mas no qual as determinações são entendidas como elementos constitutivos do sujeito, como mediações.

A apreensão do homem, como nos lembra Vigotski (2001), dar-se-á pela compreensão da gênese social do individual, "pela compreensão de como a singularidade se constrói na universalidade e, ao mesmo tempo e do mesmo modo, como a universalidade se concretiza na singularidade, tendo a particularidade como mediação" (Oliveira, 2001, p.1). Entendemos, desse modo, que o homem, ser social e singular, síntese de múltiplas determinações, nas relações com o social (universal), constitui sua singularidade através das mediações sociais (particularidades/ circunstâncias específicas). ${ }^{3}$

Assim, ao falarmos em mediação, referimonos, como afirma Severino, "a uma instância que relaciona objetos, processos ou situações entre si; a partir daí, o conceito designará um elemento que viabiliza a realização de outro que, embora distinto dele, garante a sua efetivação, dando-lhe concretude" (2002, p. 44). A categoria mediação não tem, portanto, a função de apenas ligar a singularidade e a universalidade, mas de ser o centro organizador objetivo dessa relação. Ao utilizarmos a categoria mediação, possibilitamos a utilização, a intervenção de um elemento/ um processo, em uma relação que antes era vista como direta, permitindo-nos pensar em objetos/processos ausentes até então. Assim, como já colocamos acima, subjetividade e objetividade, externo e interno, nessa perspectiva, não podem ser vistos numa relação dicotômica e imediata, mas como elementos que, apesar de diferentes, se constituem mutuamente, possibilitando um a existência do outro numa relação de mediação. Nossa tarefa, portanto, é apreender as mediações sociais constitutivas do sujeito, saindo assim da aparência, do imediato, e indo em busca do processo, do não dito, do sentido. Colocadas essas questões metodológicas, destacamos, como uma questão preliminar para a discussão dos sentidos e significados, a relação pensamento - linguagem.

Muitos autores têm debatido esse tema; assim, faremos uma breve retomada de alguns pontos essenciais para essa discussão.

Retomando nossas reflexões sobre a constituição dialética do homem, podemos afirmar que o plano individual não constitui mera transposição do social. O indivíduo modifica o social, transforma o social em psicológico e, assim, cria a possibilidade do novo. Isso posto, podemos afirmar que a linguagem seria o instrumento fundamental nesse processo de constituição do homem. "Os Signos, entendidos como instrumentos convencionais de natureza social, são os meios de contato com o mundo exterior e também do homem consigo mesmo e com a própria consciência" (Aguiar, 2000, p. 129). ${ }^{4}$

Assim, os signos, instrumentos psicológicos, são constitutivos do pensamento não só para comunicação, mas também como meio de atividade interna. A palavra, signo por excelência, representa o objeto na consciência. Podemos, desse modo, afirmar
3 Ver mais sobre tais questões em Lukács, G. Estética: Categorias Básicas de lo Estético. Tomo 3. Barcelona $M$ é x $i$ c o , D.F: Grijalbo, 1967.

4 No artigo Sentido e Significação - sobre Significação e Sentido: uma Contribuição à Proposta de Rede de Significados, in Rede de Significações, $E d$. Artmed, 2004, Smolka,A.L.B. discute mais profundamente a questão do Signo. 
que os signos representam uma forma privilegiada de apreensão do ser, pensar e agir do sujeito.

Como afirma Vigotski, "O Pensamento não se exprime na palavra, mas nela se realiza" (2001, p.409), podendo, muitas vezes, "o pensamento fracassar", não se realizando como palavra. Dessa forma, para que se possa compreender o pensamento, entendido aqui como sempre emocionado, temos que analisar seu processo, que se expressa na palavra com significado e, ao apreender o significado da palavra, entendemos o movimento do pensamento.

Temos, assim, que a relação pensamentolinguagem não pode ser outra que não uma relação de mediação, na qual, ao mesmo tempo em que um elemento não se confunde com o outro, não pode ser compreendido sem o outro, onde um constitui o outro.

O pensamento passa, portanto, por muitas transformações para ser expresso em palavras, de modo a concluir-se que a transição do pensamento para a palavra passa pelo significado e o sentido. Dessa forma, podemos afirmar que a compreensão da relação pensamento/ linguagem passa pela necessária compreensão das categorias significado e sentido.

Isso posto, destacamos a necessidade da discussão das categorias significado e sentido. Apesar de optarmos iniciar pela discussão da categoria significado, faz-se necessário explicitar que essas duas categorias, apesar de serem diferentes, de não perderem sua singularidade (fato que nos leva a discuti-las em separado), não podem ser compreendidas descoladas uma da outra, pois uma não existe sem a outra.

Segundo Vigotski, (2001), o significado, no campo semântico, corresponde às relações que a palavra pode encerrar; já no campo psicológico, é uma generalização, um conceito.
Na verdade, o homem transforma a natureza e a si mesmo na atividade, e é fundamental que se entenda que esse processo de produção cultural, social e pessoal tem como elemento constitutivo os significados. Dessa maneira, a atividade humana é sempre significada: o homem, no agir humano, realiza uma atividade externa e uma interna, e ambas as situações (divisão essa somente para fins didáticos) operam com os significados. Nessa perspectiva, Vigotski (2001) lembra que o que internalizamos não é o gesto como materialidade do movimento, mas a sua significação, que tem o poder de transformar o natural em cultural.

Os significados são, portanto, produções históricas e sociais. São eles que permitem a comunicação, a socialização de nossas experiências. Muito embora sejam mais estáveis, "dicionarizados", eles também se transformam no movimento histórico, momento em que sua natureza interior se modifica, alterando, em conseqüência, a relação que mantêm com o pensamento, entendido como um processo.

Os significados referem-se, assim, aos conteúdos instituídos, mais fixos, compartilhados, que são apropriados pelos sujeitos, configurados a partir de suas próprias subjetividades.

Ao discutir significado e sentido, é preciso compreendê-los como constituídos pela unidade contraditória do simbólico e do emocional. Dessa forma, na perspectiva de melhor compreender o sujeito, os significados constituem o ponto de partida: sabe-se que eles contêm mais do que aparentam e que, por meio de um trabalho de análise e interpretação, pode-se caminhar para as zonas mais instáveis, fluidas e profundas, ou seja, para as zonas de sentido. Afirma-se, assim, que o sentido é muito mais amplo que o significado, pois o primeiro constitui a articulação dos eventos psicológicos que o 
sujeito produz frente a uma realidade. Como coloca Gonzalez Rey (2003), o sentido subverte o significado, pois ele não se submete a uma lógica racional externa. O sentido refere-se a necessidades que, muitas vezes, ainda não se realizaram, mas que mobilizam o sujeito, constituem o seu ser, geram formas de colocá-lo na atividade. O sentido deve ser entendido, pois, como um ato do homem mediado socialmente. A categoria sentido destaca a singularidade historicamente construída. Como coloca Namura,

"A análise da relação do sentido com a palavra mostrou que o sentido de uma palavra nunca é completo, é determinado, no fim das contas, por toda a riqueza dos momentos existentes na consciência.[....]o sentido da palavra é inesgotável porque é contextualizado em relação à obra do autor, mas também na compreensão do mundo e no conjunto da estrutura interior do indivíduo" (2003, p.185).

Fica evidenciada, desse modo, a complexidade de tal categoria, fato que, sem dúvida, gera grande dificuldade nas formas de apreendêla. No entanto, é esse o caminho que nos propomos a seguir: apreender o processo constitutivo dos sentidos bem como os elementos que engendram esse processo. Queremos apropriar-nos daquilo que diz respeito ao sujeito, daquilo que representa o novo, que, mesmo quando não colocado explícita ou intencionalmente, é expressão do sujeito, configurado pela unicidade histórica e social do sujeito, revelação das suas possibilidades de criação.

O sentido coloca-se em um plano que se aproxima mais da subjetividade que com mais precisão expressa o sujeito, a unidade de todos os processos cognitivos, afetivos e biológicos. No entanto, dada a sua complexidade, afirmamos como nossa possibilidade aproximarmo-nos de algumas zonas de sentido.
Para que se possa melhor compreender a categoria sentido, retomamos um dos princípios do materialismo dialético: a unidade contraditória existente na relação simbólico emocional. Para se avançar na compreensão do homem, ou melhor dizendo, dos seus sentidos, temos que, nas nossas análises, considerar que todas as expressões humanas sejam cognitivas e afetivas.

Concordamos com González Rey (2003) ao afirmar que o pensamento é um processo psicológico, não só por seu caráter cognitivo, mas por ser sentido subjetivo, pelas significações e emoções que se articulam em sua expressão.

Como afirma Heller, “...não pode haver um rosto completamente desprovido de expressão" (1986, p .74). Segundo a autora (1986), o sentir - seja positiva ou negativamente, sempre significa estar implicado em algo; a implicação vai, assim, ser vista como um fator constitutivo e inerente do atuar e do pensar. As emoções não podem, assim, ser vistas como passivas, como epifenômenos. Em Teoria da Emoções, Vygotski, citando Spinosa, destaca o aspecto fundamental e constitutivo dos afetos: “...afetos são estados corporais que aumentam ou diminuem a capacidade do corpo para a ação, favorecem-na ou limitam-na, assim como as idéias que se tem sobre esses estados"( 2004, p.16).

Na perspectiva adotada, portanto, a separação entre pensamento e afeto jamais poderá ser feita, sob o risco de fechar-se definitivamente o caminho para a explicação das causas do próprio pensamento, pois a análise do pensamento pressupõe necessariamente a revelação dos motivos, necessidades e interesses que orientam o seu movimento. Desse modo, além de apontarmos a relação dialética entre o aspecto afetivo e o simbólico, destacamos a importância de agregarmos a noção de necessidade e motivos para a
Entendemos, dessa form"A análise da relação do sentido com a palavra mostrou que o sentido de uma palowra nunca é completo, é determinado, no fim das contas, por toda a riqueza dos momentos existentes na consciência.[....]a, que indivíduo e sociedade não mantêm uma relação isomórfica entre si, mas uma relação onde um constitui o outro.

Namura
5 Em Sujeito e Subjetividade, São Paulo: Ed. Thomson, S.P, 2003 , Gonzalez Rey faz uma discussão aprofundada sobre a questão das emoçóes, necessidades e motivos. 
compreensão do sujeito e, assim, dos sentidos. Isso posto, vemos como importante, mesmo que de maneira breve, apresentarmos algumas reflexões feitas no campo da Psicologia sociohistórica sobre esses conceitos. As necessidades são entendidas como um estado de carência do indivíduo que leva a sua ativação com vistas a sua satisfação, dependendo das suas condições de existência. Temos, assim, que as necessidades se constituem e se revelam a partir de um processo de configuração das relações sociais, processo esse que é único, singular, subjetivo e histórico ao mesmo tempo. Além disso, é fundamental ressaltar que, pelas características do processo de configuração, o sujeito não necessariamente tem o controle e, muitas vezes, a consciência do movimento de constituição das suas necessidades. Assim, tal processo só pode ser entendido como fruto de um tipo específico de registro cognitivo e emocional, ou seja, a constituição das necessidades se dá de forma não intencional, tendo nas emoções um componente fundamental. Pode-se dizer que tais registros constitutivos das necessidades não são necessariamente provenientes das significações, podendo constituir-se em afecções que ainda não foram significadas. Como coloca González Rey, "Se a emoção diz não, os meios não estão disponíveis.... A emoção é que define a disponibilidade dos recursos subjetivos do sujeito para atuar" (2003, p. 245).

Evidencia-se, desse modo, a complexidade desse processo, marcado especialmente pela força dos registros emocionais, geradores de um estado de desejo, de tensão, que mobiliza o sujeito, que cria experiências afetivas que, como atividade psíquica, têm papel regulador. Esse estado emocional, que mobiliza, que, como nos aponta González Rey, “...caracteriza o estado do sujeito ante toda a ação fundamental" (2003, p.242), deve ser analisado para chegarmos aos sentidos. Mas ainda falta um elo. Essas necessidades, vividas como estado dinâmico, ainda não dão uma direção ao comportamento. Esse processo, de ação do sujeito no mundo a partir das suas necessidades, só vai completar-se quando o sujeito significar algo do mundo social como possível de satisfazer suas necessidades. Aí sim, esse objeto/fato/pessoa vai ser vivido como algo que impulsiona/direciona, que motiva o sujeito para a ação no sentido da satisfação das suas necessidades. Tal movimento, ou seja, a possibilidade de realizar uma atividade que vá na direção da satisfação das necessidades, com certeza modifica o sujeito, criando novas necessidades e novas formas de atividade. Afirmamos, assim, que a necessidade não conhece seu objeto de satisfação, ela completa sua função quando o "descobre" na realidade social. Entendemos que esse movimento se define como a configuração das necessidades em motivos. Com isso, estamos dizendo que os motivos se constituirão como tal somente no encontro com o sujeito, no momento que o sujeito o configurar como possível de satisfazer as suas necessidades.

Ao se apreender o processo por meio do qual os motivos se configuram, avança-se na apropriação do processo de constituição dos sentidos, definidos como a melhor síntese do racional e do emocional. Aproximamo-nos, dessa forma, do processo gerador da atividade, ao mesmo tempo gerado por ela. Apreendemos o que é a atividade para o sujeito, e, assim, algumas zonas de sentidos da atividade, claro que atravessadas pelos significados, mas, no caso, revelando uma forma singular de vivê-las e articulá-las.

A apreensão dos sentidos não significa apreendermos uma resposta única, coerente, absolutamente definida, completa, mas expressões do sujeito muitas vezes contraditórias, parciais, que nos apresentam indicadores das formas de ser do sujeito, de processos vividos por ele. 
Sabemos o quão difícil é sua apreensão; ele não se revela facilmente, não está na aparência; muitas vezes, o próprio sujeito o desconhece, não se apropria da totalidade de suas vivências, não as articula.

Não podemos esquecer que o pensamento, sempre emocionado, não pode ser entendido como algo linear, fácil de ser captado; não é algo pronto, acabado. É interessante quando Vigotski afirma que o pensamento muitas vezes termina em fracasso, não se converte em palavras. Com essa afirmação, podemos entender que vivências ocorrem, que um processo está ocorrendo, mas que não se expressa claramente, ou nem é significado claramente, objetivamente, e, assim, podemos concluir que as vivências são muito mais complexas e ricas do que parecem.

Então, como apreendê-las?

Que caminho nos conduziria a tal tarefa?

\section{Procedimentos para análise através dos núcleos de significação}

Antes de entrarmos no tema da análise, consideramos adequada a apresentação de alguns apontamentos sobre a "coleta" de material a ser analisado, isto é, os procedimentos e instrumentos recomendados para uma investigação dentro da abordagem sociohistórica. Não são procedimentos ou instrumentos exclusivos, mas fundamentais para os nossos objetivos dentro de uma proposta de pesquisa qualitativa.

Neste artigo, trabalharemos com entrevistas, do nosso ponto de vista, um dos instrumentos mais ricos e que permitem acesso aos processos psíquicos que nos interessam, particularmente os sentidos e os significados. Sem a pretensão de ampliar uma discussão sobre esse método de coleta, gostaríamos de atentar para algumas características que marcam esse instrumento e que, sem dúvida, interferem no seu potencial de captação ou apreensão dos sentidos e significados buscados.

- as entrevistas devem ser consistentes e suficientemente amplas, de modo a evitar inferências desnecessárias ou inadequadas;

- elas devem ser recorrentes, isto é, a cada entrevista, após uma primeira leitura, o informante deverá ser consultado no sentido de eliminar dúvidas, aprofundar colocações e reflexões e permitir uma quase análise conjunta do processo utilizado pelo sujeito para a produção de sentidos e significados;

- mesmo considerando que uma boa entrevista possa contemplar material suficiente para uma análise, se houver condições, alguns outros instrumentos podem permitir aprimoramento e refinamento analítico. Para isso, recomenda-se um plano de observação no processo das entrevistas, tanto para captar indicadores não verbais como para complementar e parear discursos e ações que estejam nos objetivos da investigação.

Outros instrumentos úteis e possíveis de utilização: relatos escritos, narrativas, história de vida, frases incompletas, autoconfrontação, vídeo-gravação e, inclusive, questionários ou desenhos, desde que sejam complementados e aprofundados através de entrevistas.

\section{Leitura flutuante e organização do material}

\section{Os pré-indicadores}

Consideramos que a palavra com significado seja a primeira unidade que se destaca no momento ainda empírico da pesquisa. Partimos dela sem a intenção de fazer mera análise das construções narrativas, mas com a intenção de fazer uma análise do sujeito. Assim, temos que partir das palavras inseridas no contexto que Ihes atribui significado, entendendo aqui como contexto desde a
6 Para mais detalhes sobre essa questão, consultar: Ozella, S.: Pesquisar ou Construir Conhecimento. O Ensino da Pesquisa na $A b \circ r d$ a $g e m$ Sociohistórica. In Ana M.B.Bock (org.) A $\mathrm{P}$ e r s p e c t i v a Sociohistórica na Formação em Psicologia S.Paulo: Ed. Vozes, 2003 pp.113-131; González Rey, Fernando: La Investigación Cualitativa en Psicologia: Rumbos y Desafios. São Paulo: Educ, 1999; Vigotski, Lev Semenovich: A Formação Social da Mente. São Paulo: Martins Fontes, 1998. 
narrativa do sujeito até as condições históricosociais que o constituem.

Tendo o material gravado e transcrito, iniciamos várias leituras "flutuantes", para que possamos, aos poucos, nos familiarizar, visando a uma apropriação do mesmo. Essas leituras nos permitem destacar e organizar o que chamaríamos de pré-indicadores para a construção dos núcleos futuros. Irão emergindo temas os mais diversos, caracterizados por maior freqüência (pela sua repetição ou reiteração), pela importância enfatizada nas falas dos informantes, pela carga emocional presente, pelas ambivalências ou contradições, pelas insinuações não concretizadas, etc. Geralmente, esses préindicadores são em grande número e irão compor um quadro amplo de possibilidades para a organização dos núcleos. Um critério básico para filtrar esses pré-indicadores é verificar sua importância para a compreensão do objetivo da investigação.

\section{Os indicadores e conteúdos temáticos}

Uma segunda leitura permitirá um processo de aglutinação dos pré-indicadores, seja pela similaridade, pela complementaridade ou pela contraposição, de modo que nos levem a menor diversidade; já no caso dos indicadores, que nos permitam caminhar na direção dos possíveis núcleos de significação. Esses critérios para aglutinação não são necessariamente isolados entre si. Por exemplo, alguns indicadores podem ser complementares pela semelhança do mesmo modo que pela contraposição: um fato identificado como préindicador, ao ser aglutinado, pode indicar o caráter impulsionador/motivador para ação em uma determinada condição. Inversamente, o mesmo fato pode funcionar como paralisador da ação em outro momento, mas ambos podem ser indicadores importantes no processo de análise.
Esse procedimento tem analogia com o que coloca Vigotski (1998, p.182) quando fala das peculiaridades semânticas da fala interior e destaca a aglutinação como uma delas: "Quando diversas palavras se fundem numa única, a nova palavra não expressa apenas uma idéia de certa complexidade, mas designa todos os elementos isolados contidos nessa idéia".

Tentaremos aqui ilustrar com exemplos esse processo, que resultará de dois elementos: os indicadores e sua relação com situações ou conteúdos temáticos. Um exemplo que pode esclarecer a organização de pré-indicadores e indicadores pode ser encontrado no Anexo 1.

A partir dos pré-indicadores identificados, podemos avançar para indicadores do tipo: violência, drogas, gravidez, sexualidade, família, escola, consumismo, religiosidade, medo, alegria, tristeza, prazer, etc. Entretanto, tais indicadores podem ter significados diferentes dentro de condições específicas (lembrem-se dos critérios de aglutinação citados acima: semelhança, complementaridade, contraposição). Um indicador como a violência pode ter potências e coloridos diferentes em condições diversas, tais como: fases ou etapas de sua trajetória na vida, nas relações com "outros" (família, trabalho, autoridades, namorada), em experiências de vida, etc. Estes seriam os conteúdos temáticos junto aos quais os indicadores adquirem algum significado. De posse desse conjunto (os indicadores e seus conteúdos), devemos, nesse momento, voltar ao material das entrevistas e iniciar uma primeira seleção dos trechos que ilustram e esclarecem os indicadores.

Esse momento já caracteriza uma fase do processo de análise, mesmo que ainda empírica e não interpretativa, mas que ilumina um início de nuclearização. 


\section{Construção e análise dos núcleos de significação}

\section{A construção dos núcleos de significação}

A partir da re-leitura do material, considerando a aglutinação resultante (conjunto dos indicadores e seus conteúdos), iniciamos um processo de articulação que resultará na organização dos núcleos de significação através de sua nomeação. Os indicadores são fundamentais para que identifiquemos os conteúdos e sua mútua articulação de modo a revelarem e objetivarem a essência dos conteúdos expressos pelo sujeito. Nesse processo de organização dos núcleos de significação - que tem como critério a articulação de conteúdos semelhantes, complementares ou contraditórios -, é possível verificar as transformações e contradições que ocorrem no processo de construção dos sentidos e dos significados, o que possibilitará uma análise mais consistente que nos permita ir além do aparente e considerar tanto as condições subjetivas quanto as contextuais e históricas. Espera-se, nessa etapa, um número reduzido de núcleos, de modo que não ocorra uma diluição e um retorno aos indicadores. É nesse momento que, efetivamente, iniciamos o processo de análise e avançamos do empírico para o interpretativo, apesar de todo o procedimento ser, desde o início da entrevista, um processo construtivo/interpretativo ${ }^{7}$. Os núcleos resultantes devem expressar os pontos centrais e fundamentais que trazem implicações para o sujeito, que o envolvam emocionalmente, que revelem as suas determinações constitutivas.

Uma sugestão para a nomeação dos núcleos é extrair da própria fala do informante uma ou mais de suas expressões, de modo a compor uma frase curta que reflita a articulação realizada na elaboração dos núcleos e que explicite o processo e o movimento do sujeito dentro dos objetivos do estudo.

\section{A análise dos núcleos}

A análise se inicia por um processo intranúcleo, avançando para uma articulação internúcleos. Em geral, esse procedimento explicitará semelhanças e/ou contradições que vão novamente revelar o movimento do sujeito. Tais contradições não necessariamente estão manifestas na aparência do discurso, sendo apreendidas a partir da análise do pesquisador. Do mesmo modo, o processo de análise não deve ser restrito à fala do informante, ela deve ser articulada (e aqui se amplia o processo interpretativo do investigador) com o contexto social, político, econômico, em síntese, histórico, que permite acesso à compreensão do sujeito na sua totalidade.

Como nos lembra Vigotski (1998), um corpo só se revela no movimento. Assim, só avançaremos na compreensão dos sentidos quando os conteúdos dos núcleos forem articulados. Nesse momento, temos a realização de um momento da análise mais complexo, completo e sintetizador, ou seja, quando os núcleos são integrados no seu movimento, analisados à luz do contexto do discurso em questão, à luz do contexto sociohistórico, à luz da teoria.

Parece-nos importante insistir que o procedimento adotado visa a avançarmos do empírico para o interpretativo, isto é, da fala para o seu sentido, entendendo que vamos em busca da fala interior, ou seja, a partir da fala exterior caminhamos para um plano mais interiorizado, para o próprio pensamento (Vigotski, 1998, p.185).

Caminhando na compreensão dos sentidos, relembramos a importância da análise das determinações constitutivas do sujeito, e, para isso, é importante apreendermos as necessidades, de alguma forma colocadas pelos sujeitos e identificadas a partir dos indicadores. Entendemos que tais necessidades são
7 Consultar obras citadas na nota de rodapé número 
determinantes/constitutivas dos modos de agir/sentir/pensar dos sujeitos. São elas que, na sua dinamicidade emocional, mobilizam os processos de construção de sentido e, é claro, as atividades do sujeito.

Para tentarmos deixar mais claro o processo por nós utilizado na análise de pesquisas por intermédio dos núcleos de significação, faremos uso de alguns exemplos retirados de dissertações e teses de alunos que estiveram sob nossa orientação nos programas de estudos pós-graduados em Psicologia social e Psicologia da educação da Pucsp. Os exemplos não pretendem ser modelos concluídos e irrepreensíveis do processo. Seu objetivo é ilustrar o processo, mesmo apresentando uma ou outra falha, já que cada análise é única e encontra-se dentro de um momento contínuo de construção e aprimoramento.

Serão utilizados dois trabalhos. Inicialmente, referir-nos-emos à tese de doutorado de Célia Ferreira Novaes, As determinações sociais no problema da escolha profissional: contradições e angústias nas opções dos jovens das classes sociais de alta renda, desenvolvida no Programa de Psicologia social, em 2003, sob orientação do professor Sergio Ozella. Em seguida, ilustraremos com a dissertação de mestrado de Agnes Maria Gomes Murta, de 2004, no Programa de Psicologia da educação, orientada pelo professora Wanda Maria Junqueira de Aguiar, Contribuições da Psicologia sociohistórica para a educação inclusiva.

Cada uma delas teve razões específicas para ser escolhida como exemplo e não necessariamente ilustram de maneira perfeita todo o processo, mas servem como referência para ao menos uma das etapas identificadas no início desta seção.

Novaes, Célia Ferreira - As determinações sociais no problema da escolha profissional: contradições e angústias nas opções dos jovens de classes sociais de alta renda.

Como apresenta logo no início de seu resumo, Célia pretendeu, com seu estudo, "compreender as contradições existentes na construção de problema da escolha profissional, geradoras de sofrimento nos adolescentes das classes sociais e econômicas de alta renda..." e completa, no seu capítulo metodológico, que o fará através da apreensão do "conjunto de significados e sentidos que compõem a construção do problema da escolha profissional" (p. 116).

A autora justifica o interesse em estudar a população de alta renda da seguinte maneira: "Em geral, encontramos trabalhos relativos ao sofrimento daqueles que não dispõem de muitas possibilidades de escolhas profissionais, constituídos pelos grupos sociais onde se concentra a parcela da população economicamente carente ou marginalizada, excluída da educação formal de qualidade e de um conjunto de condições que facilitam o acesso às melhores oportunidades de trabalho.[...] Entretanto, esses jovens (de classe alta) estão também sendo forjados nesta mesma sociedade de cuja dinâmica extraem os elementos a partir dos quais constroem os ideais e valores que respaldam suas ações, enquanto agentes privilegiados que contribuirão, no exercício de suas profissões, para o processo de construção desta mesma sociedade.[...] A classe social é uma referência a valores que definem possibilidades, limites e contradições [grifo nosso]" (p. 4).

O sujeito da investigação foi um jovem (Rafael) em processo de orientação profissional na PucRJ. Cursava o $3^{\mathfrak{0}}$ ano do ensino médio em uma escola bilíngüe da zona sul da cidade. Pertencia a uma família de altíssimo nível socioeconômico, residia em um condomínio fechado e tinha sido alfabetizado na Europa. O material foi resultado de entrevistas 
individuais ocorridas durante as sessões de orientação profissional, que compuseram um total de 15 encontros.

A partir da organização das entrevistas, que resultaram nos indicadores e nos conteúdos importantes para o objetivo do estudo, Célia construiu seis núcleos de significação:

a realidade que o confunde e incomoda;

- a experiência estética das profissões reificadas;

- a vida sob controle ou o atrevimento do real;

- o prazer como causa e conseqüência ;

- as contradições e ambigüidades entre a autonomia protegida e a rotina sempre nova; - a condição de impotência do ser natural.

Por problemas de espaço editorial, iremos aqui ilustrar a análise com apenas um dos núcleos. Entretanto, todos eles, de alguma forma, estão muito inter-relacionados e imbricados entre si, configurando a integração pretendida no procedimento proposto anteriormente.

\section{A experiência estética da profissão reificada}

Esse núcleo se constituiu a partir das narrativas referentes às duas profissões que pautavam a dúvida de Rafael: a Medicina e o Direito.

“...acho a Medicina legal porque é a maior adrenalina ...tem sempre um caso novo ...uma história toda complicada pra gente resolver ...tem várias pessoas pra resolver junto com você ...você tem a maior galera pra ajudar você."

Quanto ao Direito, sua referência pode ser identificada como:

“...aquela roupa ridícula ...tem que ler muito, os livros são enormes ...é muito tudo sozinho ...ali na hora você decide a parada, tem que convencer as pessoas, e se errar? ...também é uma profissão poderosa como a Medicina."
... ambas as profissões têm algo em comum, sedutor e glamuroso. São afirmações explicadas principalmente por imagens, onde a compreensão do que sejam as profissões se faz a partir de experiências marcadamente visuais:

“...eu não consigo ver quando tem operação e tiram as partes de dentro da gente, o cara coloca a mão, não gosto de olhar."

A referência às profissões parece moldada por relações sensíveis, segundo Rafael, oriundas de filmes da TV, que agradam aos sentidos e excitam o sujeito.

Rafael se refere à profissão como um produto, cujo uso deve agregar valor a quem o possui e identificar o sujeito enquanto classe de consumidor a que pertence:

“...lugar desvalorizado ...num lugar que não te valorizam ...deve ter coisa melhor que Medicina ...coisa que eu goste mais, me der melhor" (p.128).

É interessante destacar aqui como a autora conduz sua análise. Célia articula dados do sujeito, quebra a seqüência cronológica da entrevista e busca a articulação entre fatos até então não articulados pelo sujeito, revela relações, e, para isso, recorre, além das categorias de análise da sociohistórica, a conteúdos de outras áreas das ciências humanas e sociais para explicar (por exemplo) o poder da mídia na constituição dos sujeitos. A autora continua sua análise:

"A escolha se faz sobre um conjunto de profissões-coisas que são avaliadas pelo seu valor de troca na sociedade, quanto de retorno poderá ser obtido com sua posse. Há um distanciamento do sujeito com a função social do exercício das profissões, avaliadas como produtos para uso, consumo e troca... A hierarquização das profissões, feita pelas escolas, e o respectivo status daqueles que as escolhem, participam, também, da 
configuração desse núcleo de significação. Assim,

'...Publicidade exige menos estudo do que Medicina ...não é tão valorizada ...o pessoal de Medicina acha que é melhor que os outros ...eu também achava.'

O status pessoal é denotado pelo status da profissão reificada, cujo valor revela o status de quem a possui "(p.128).

Mais adiante, Célia considera o papel da mídia na produção de significados sobre as profissões. Senão vejamos:

[....] Na sociedade apresentada pela mídia, só se colocam

problemas que ela é capaz de solucionar. Há uma permanente

relação entre os desejos e os meios para a sua realização, negando as condições concretas em que vivemos"(p.139).

Rocha
8 Rocha, Everaldo. A Sociedade do Sonho. Rio de Janeiro: Mauad Editora, 1995.
"Rafael compreende a Medicina, antes de tudo, pela simbologia de poder e glamour que acompanham a apresentação das profissões na mídia, para a qual só interessam os seus aspectos isolados, quer seja nas publicidades, nos seriados, filmes ou novelas. A profissão costuma ser parte do contexto do produto que pretende vender ou do personagem que a representa, não tendo qualquer antecedente que a comprometa num tempo histórico ou numa realidade social complexa. A Medicina que é apresentada por Rafael está destituída de história, são fragmentos de imagens e movimentos em que estão ausentes os elementos concretos que constituem as relações de produção e o trabalho. $\mathrm{Na}$ verdade, sua Medicina não está inserida em qualquer relação econômica, tudo é funcionalmente articulado para o final feliz, isto é, aquele que faz sentido para o roteiro. Isoladamente, nada é absurdo, mas tudo é acrítico. Essa experiência guarda uma perigosa proximidade com outros aspectos do cotidiano de Rafael" (p.139).

Outro destaque a ser feito se refere ao uso da literatura, não se prendendo apenas às falas do sujeito, para justificar, e, dessa forma, ampliar e contextualizar suas considerações. "Rocha (1995) ${ }^{8}$ nos mostra que a sociedade na mídia é uma sociedade de abundância, resolvida e absolutamente bem sucedida economicamente, sem nenhuma ênfase no trabalho para que isso aconteça.[...] $\mathrm{Na}$ sociedade apresentada pela mídia, só se colocam problemas que ela é capaz de solucionar. Há uma permanente relação entre os desejos e os meios para a sua realização, negando as condições concretas em que vivemos" (p.139).

A autora continua sua análise, agora contextualizando e teorizando (sobre) suas reflexões.

"Vários contextos contribuem como processos mediadores da construção da subjetividade de Rafael, de seus sentidos pessoais sobre o problema que atravessa e suas possíveis soluções. Suas múltiplas relações intersubjetivas servem de mediadores para a conversão desses contextos e seus significados para o plano intra-subjetivo e de sentidos pessoais de Rafael."... "Compreender a cultura e o conjunto de relações sociais em que Rafael está inserido e suas atividades interativas concretas no cotidiano permite-nos compreender os sistemas de signos que medeiam e configuram o processo de subjetivação de Rafael, como sente e interpreta a realidade a sua volta" (p.140).

Nesse trecho, vale destacar novamente o cuidado da autora em articular a construção dos sentidos de seu informante com suas vivências, suas experiências, como a soma dos eventos psicológicos despertados pela palavra. Desse modo, fica clara a importância da teoria e da contextualização para chegarmos aos sentidos entendidos (como dito anteriormente neste texto) como atos do homem mediados socialmente.

Celia conclui, articulando seus sentidos e significados com o grupo social onde Rafael está imerso.

"Rafael constrói a experiência do seu grupo social enquanto é por ele constituído, através das significações que produz a partir das 
funções distintivas de sua classe social. Essas funções se realizam por diversos aspectos, pela posse de determinados objetos, pelo tipo e forma de consumo e freqüência a lugares e, também, por práticas e partilhas de significados que são formas de ser e vivências emocionais, configurando o mundo de Rafael e ensejando novas experiências reais em sua vida" (p.140).

\section{O prazer como causa e conseqüência}

Nesse núcleo, a autora trabalha um dos aspectos centrais no discurso de Rafael, relacionando-o com o caráter hedonista presente nos jovens, particularmente nos do segmento socioeconômico de Rafael e que parece nortear não apenas suas escolhas profissionais mas também sua própria vida.

"Escolher aparece fortemente vinculado ao prazer como critério decisório e que, ao ser atendido, efetivamente deverá levar a um resultado igualmente prazeroso. Todo o processo seria um único momento de um prazer que se expande. A certeza de Rafael de que isso é possível vem de sua experiência de vida. Frente ao que Ihe desagrada, ele simplesmente não olha, troca de canal, como nas cenas dos filmes de TV que lhe desagradam ou apenas exclui, como as partes da cidade onde mora,

'...eu até penso nisso, mas não vejo saída e aí, desligo.'

Afirma que, quando está a fim de alguma coisa, sempre a consegue, seja passar de ano no colégio, seja um carro novo. Sua preocupação principal não é com seu desempenho na profissão, mas com a manutenção de um estado de prazer com o que vai fazer, que, por sua vez, é a garantia do sucesso. Esse gostar não só deve existir no momento da escolha como deve manter-se no futuro, condição para que permaneça exercendo qualquer profissão"(p.129).
A autora enfatiza o caráter e a importância desse núcleo de significação,

“O prazer como causa e conseqüência, em si mesmo, é essencial em qualquer avaliação que faz, se constitui na métrica daquilo que ele observa, analisa, consome e decide, isto é, a realidade é aferida pelo estado de ânimo que propicia. É ponto de partida, processo e objetivo. Rafael diz que quer encontrar algo de que goste, e que só assim vai querer estudar e terá garantido o sucesso e a realização profissional. Os atributos da profissão deverão fazê-lo sentir-se animado o suficiente para querer tal profissão. Ele a quer porque ela é uma garantia de que terá prazer. Pode inclusive não ser a Medicina, pois indaga sobre se

'...tem alguma coisa que eu possa gostar mais ...que seja melhor pra mim.'

Mas não pode ser qualquer outra profissão, tem que preencher seus vários critérios, numa liberdade de escolha que só permite um resultado - o sucesso em todas as suas nuances" (p.149).

Mais adiante, Célia tenta compreender melhor a questão do compromisso e do custobenefício presente nas decisões de Rafael.

"Rafael define a dose de compromisso que está disposto a investir, o tempo em que permanecerá na sessão e o término dos assuntos abordados. Tem dificuldade para se comprometer com o outro, despejando informações, fatos, alegrias e sofrimentos sem se deter sobre sua própria história.

'...Eu até penso nisso, mas não vejo saída e aí, desligo.'

Mais que um processo de defesa circunstancial, é uma forma de lidar com a experiência do cotidiano e um estilo de vida. Não lhe ocorre procurar ou construir saídas que dependam 
de si mesmo, de sua persistência ou esforço, pois os mecanismos de delegar as soluções de seus problemas e o de desligar-se do que não gosta já the são familiares e sempre funcionaram"(p.150). E continua:" Rafael não pretende deter-se muito tempo sobre os mesmos fatos. Seus momentos estão sempre repletos de fazeres, exigindo uma dispersão competente para conseguir, ao mesmo tempo, marcar programas com amigos, resolver seus problemas de estudo, atender às demandas que the chegam pelo telefone celular, enquanto lida com os próprios sentimentos durante a nossa relação de orientação. Rafael se liga e se desliga de um assunto para o outro, num fluxo de fatos e emoções que carecem de reflexão (p. 150).

Rafael configura a escolha profissional de acordo com o seu cotidiano, que ele não quer ver mudado porque '...minha vida é muito manera.' Não se trata de querer manter-se criança, muito pelo contrário, a infância impõe limites e barreiras indesejáveis, mas de ter uma vida adulta repleta das possibilidades avidamente desejadas, ampliando espaços e liberdades. Rafael quer ser adulto não com as facilidades infantis que são muito tímidas para seus anseios, mas com as condições, possibilidades e ações, sem conseqüências adversas, com as quais convive no universo dos adultos que o cercam. É um modelo de adultez que o inspira e não o retorno a modelos infantis (p.150).

A preferência profissional de Rafael, portanto, depende da capacidade potencial de que algum curso suscite o seu gostar e que lhe permita vislumbrar sensações novas e prazerosas que, por sua vez, desencadeiem novos desejos, isto é, a profissão deve atender ao desejo de ser capaz de desencadear novos desejos e assim sucessivamente. Para Rafael, as profissões têm que extrair sentido de si mesmas e se autojustificarem, oferecendo sua própria legitimação em cada momento e proporcionando a maior satisfação possível.
O prazer como causa e conseqüência da escolha profissional força uma busca ansiosa de Rafael pelo curso que mais o encante, com garantias de que continuará, no futuro, gostando da escolha que fizer, '...se eu gostar vai ser legal ...não vou ter problemas' (p.151).

Subjaz uma configuração de mundo profissional que só o interessa na medida e extensão em que cumpre uma função sempre realizadora de prazer. A profissão se apresenta liberta de qualquer compromisso com o real a sua volta, da mesma forma com que Rafael recorta o mundo que o interessa e apenas por ele circula. Não se trata apenas de negar a realidade, mas de subvertê-la, travesti-la numa aparência de realidade, formando uma ilusão de sociedade adequada a seus propósitos e onde tudo é igualmente possível, basta querer '...se ele quiser fazer, que faça', como afirma a mãe de Rafael. O real fica, assim, submisso, incondicionalmente, a todas as hipóteses que se queira lançar sobre ele" (p.152).

Novamente vale a pena chamar a atenção para a maneira como a autora procura compreender e ampliar as considerações do seu sujeito integrando-o ao contexto ideológico do capitalismo que o cerca e determina seus significados e sentidos, bem como o movimento de transformação e de contradição que pode estar em processo a partir das discussões com a pesquisadora.

"Rafael convive e partilha da requerida flexibilidade para a mudança e do afrouxamento das interdições nos deslocamentos, acompanhando as práticas econômicas e as perspectivas de emprego. Saber-se móvel é agora uma qualidade que Rafael deve cultivar, porque necessita dela para cumprir suas metas de sucesso profissional, mas sente, com apreensão, a conseqüente deriva interior. A lógica do capital flexível, deslocada para trabalhadores igualmente flexíveis e contingenciais, que possam ir e vir, fluindo pelos lugares sem acusarem danos ou 
sofrimentos, encontra Rafael relutante em desprender-se do próprio passado. Nesse momento de escolha, a flexibilidade implica tanto riscos e perdas quanto soluções (p.154). Dá-se conta de que, na vida, as coisas não funcionam como na prova do vestibular que fez no ano anterior, só '...fiz para ver como era ...fazer de conta sem ter que ficar nervoso.' No que concerne a sua escolha, além de não ter um script, Rafael compreende que nem tudo pode ser ensaiado. Situações imprevisíveis constituem o tipo da novidade que ele teme, aquelas que podem expor o real que não o interessa e que fogem ao seu controle. Se falar em um projeto de vida a seguir, soa pouco atrativo porque retira a possibilidade de ser flexível e plural; fora dele, surge a insegurança. Rafael necessita sentir-se seguro, protegido e ciente de que está definitivamente certo naquilo que faz, mas suspeita que não terá as certezas sobre o caminho que escolher antes de percorrê-lo. Dá-se conta, também, de que sua liberdade de escolha é, ao mesmo tempo, gratificante e dolorosa" (p. 154).

Nas considerações finais, a autora reafirma seus objetivos e faz uma síntese de suas pretensões e do que foi atingido na sua investigação.

"Pretendemos, neste trabalho, chamar a atenção também para a importância de acompanharmos os movimentos e as transformações que vêm alterando as relações dos jovens com a educação, a informação e a escola de ensino médio, especialmente como instituição garantidora de empregos. Sem uma perspectiva crítica desse complexo relacionamento, perdemos a possibilidade de compreender o que significa a educação formal da escola para esses jovens, cuja insatisfação aponta um esvaziamento do ensino médio, percebido como um curso de passagem e tempo de sofrimento, destituído de significado próprio e sem utilidade outra que não seja, ao terminá-lo, conseguir passar para uma universidade, escamoteando-se todas as contradições desse relativo sucesso (pp.161/162).
Nossa pesquisa nos faz reconhecer os paradoxos de vidas cercadas de dispositivos de segurança que garantem a liberdade de movimento e prazer e, ao mesmo tempo, incutem o sentido de vulnerabilidade, opressão, incapacidade de superar obstáculos e medo das diferenças, paralisando suas ações. A naturalização da individualidade massificada, soberana numa sociedade invisível, desliza para a impossibilidade da ação transformadora no mundo real.

É fundamental que aprofundemos nosso conhecimento sobre as múltiplas oportunidades de construção de realidades fragmentadas que são oferecidas pela mídia e sua programação para adolescentes, plenas de materiais simbólicos de fácil digestão, incentivando consciências planas e explicações lineares do real que circulam no cotidiano dos jovens. Todo um ritmo veloz e superexcitado, predominando a cultura da ação sobre a narrativa, oferecendo referências simbólicas na ininterrupta tela eletrônica eivada de imagens e efeitos especiais, numa estimulação sem memória, numa cultura sem rastro e sem conseqüências, com primazia do tempo presente e do lazer imediato. São estilos de vida lúdico-estético-hedonistas que insistem em se colar na idéia do ser jovem enquanto uma criação da própria juventude, que efetivamente se apropria desses significados e desenvolve um sentido de participação e uma ética própria. A partir dessas concepções, cremos poder ampliar nossa compreensão sobre a profundidade e extensão com que a ambigüidade da urgência do novo, mantendo a responsabilidade solitária de manutenção dos controles sobre os resultados, afetam, estressam e paralisam os sujeitos"(pp.162/ 163).

Murta, Agnes - Contribuições da Psicologia sociohistórica para a educação inclusiva: os sentidos produzidos por professores da educação infantil de uma cidade do Vale do Jequitinhonha acerca da inclusão escolar.
São estilos de vida lúdico-estéticohedonistas que insistem em se colar na idéia do ser jovem enquanto uma criação da própria juventude, que efetivamente se apropria desses significadose desenvolve um sentido de participação e uma ética própria. 
Essa pesquisa teve como objetivo analisar o processo de constituição dos sentidos subjetivos de duas professoras de educação infantil acerca da inclusão escolar de crianças com deficiência no ensino regular (deficiências essas que geram necessidades educacionais especiais).

Foram realizadas entrevistas com quatro professoras e uma coordenadora. O critério, como não poderia deixar de ser, foi qualitativo. Desse modo, foram escolhidos profissionais que podiam falar com propriedade do tema a ser pesquisado. Dentre esses quatro, foram escolhidas duas professoras que, no entender da pesquisadora, melhor se adequavam aos propósitos da pesquisa. Com o intuito de qualificar as informações obtidas, foram realizadas cinco entrevistas recorrentes com cada professora.

Utilizaremos como exemplo apenas a análise referente a uma das professoras, denominada Ferreira.

Como coloca Agnes (p.124), partindo do pressuposto que a análise é construtiva e interpretativa, o procedimento para a apreensão dos indicadores deu-se da seguinte forma: após a transcrição, foi realizada uma leitura flutuante do material; em seguida, foram sendo levantados indicadores, ou seja, questões que se repetiam, que eram enfatizadas, que revelavam envolvimento da professora e que se mostraram importantes, considerando o objetivo da pesquisa, ou seja, apreender os sentidos e significados sobre inclusão. Como exemplo, destacamos a questão da religiosidade, que se mostrou um indicador fundamental para a organização de um dos núcleos, por atravessar e mostrar-se constitutivo de muitas das experiências vividas pela professora. Após esse momento, estavam criadas as condições para se organizar, no caso, um dos núcleos de significação, ou seja, para articularmos os conteúdos relacionados às experiências que tinham a religiosidade como elemento essencial. Com esse processo de organização dos núcleos, pretende-se, cada vez mais, criar as condições de nos apropriarmos daquelas determinações que constituem o sujeito

A autora (idem) frisa que o levantamento e organização dos núcleos de significação já constitui um momento de análise, pois o ato de "recortar" é realizado a partir dos critérios propostos pelo pesquisador, e esses critérios são sempre escolhidos em função dos objetivos da pesquisa, e, como diz Ozella (2003, p.114), "[...]nunca são neutros".

Os núcleos de significação resultantes foram:

o encontro com a religiosidade;

- ser normal ou estar deficiente: eis a questão;

o papel do professor;

inclusão/projeto creche inclusiva/sociedade inclusiva.

A título de exemplo, utilizaremos um dos núcleos: "O encontro com a religiosidade".

\section{"O encontro com a religiosidade"}

Segundo Agnes, esse núcleo é capital porque evidencia a religiosidade como um dos pontos fundamentais e constitutivos da vida de Ferreira, sendo, portanto, um aspecto essencial que atravessa a forma como ela sente, pensa e age sobre o mundo. Assim sendo, a religiosidade marca profundamente a maneira como ela atribui sentidos à inclusão, à deficiência, à sua vida profissional e às suas relações interpessoais. Entendemos que a importância dada por Agnes a esse núcleo é adequada, dado ser uma das funções centrais do núcleo de significação, que é destacar aqueles aspectos fundamentais para a compreensão do sujeito, aqueles aspectos que são constitutivos do sujeito a ser pesquisado. Para fundamentar esse movimento de análise que levantou o núcleo, Agnes destaca partes 
da fala de Ferreira que evidenciam a relevância da religiosidade em sua vida, o quanto ela foi constitutiva das suas formas de ser, pensar e sentir. Segundo Agnes (p.125), Ferreira nos revela, por meio da sua história de vida, que, por ter sido diagnosticada aos 14 anos de idade como pessoa com sofrimento mental, teve que tomar "remédio controlado", era vigiada pela família e não tinha autonomia para gerir a própria vida. "[...] os médicos falavam com minha mãe que isso (os sintomas apresentados) era um princípio de loucura". Ela relata que, nesse período, trabalhou e que não pôde estudar de forma sistemática. Após os 24 anos de idade, e a partir da intervenção de um médico espírita e da sua internação em hospital psiquiátrico no qual a Doutrina Espírita orientava a atividade de alguns profissionais, Ferreira se sente curada e ressignifica sua existência. A Doutrina Espírita passa, então, a nortear de maneira profunda a sua vida.

"(o médico) [...] fez um tratamento comigo, me desintoxicou, me internou, tirou... todo o remédio, melhorou e me deu...ânimo.

[...]

Quando ele me levou no Centro Espírita, foi onde eu melhorei, foi aonde que, que tudo pra mim mudou, que eu fui ter vida... nova. Foi onde eu tive minha vida renovada, minha vida melhorou, porque, eu... eu vi a vida com outros olhos, eu não precisava de ninguém mais pra ficar me vigiando."

Ferreira deixa claro como o período compreendido entre os 14 e 24 anos foi doloroso e o quanto ser considerada "doente" a incomodava. Dessa forma, após "sua cura", de pessoa que necessitava da ajuda de outros, passa a ajudar. Ajudar os outros se torna, então, sua filosofia de vida. Fica evidente o prazer e a felicidade que ela sente em tomar a responsabilidade de sua própria vida para si e o prazer de dedicá-la à ajuda ao próximo.

“[...] o médico falou que eu tinha que tomar remédio. Depois que eles (os familiares) viram que o remédio estava me deixando daquela maneira.... [...] Assim, me deixando... é, ... apática. Então eles ficaram preocupados. Como é que eles iam deixar eu sair sozinha pra ir pra algum lugar.... Então o dia que eu... me internei,.... o doutor falou que eu não tinha nada, que eu ia melhorar, esse dia eu renasci pra vida.[..]a doença que eles achavam que eu tinha era um engano, não era doença, porque mediunidade não é doença.... Aí comecei a decidir minha vida, a andar sozinha.[...]O que faziam comigo eu comecei a fazer pras pessoas [.......]E assim, comecei a ajudar as pessoas mais... humildes que me procuravam, porque eu comecei a trabalhar no espiritismo."

Na sua análise, Agnes destaca que a fala de Ferreira traz à tona sentimentos e emoções sobre sua forma de ser e agir no mundo "antes e depois da sua cura". Num esforço de análise e portanto, de apreensão do processo de constituição dos sentidos configurados por Ferreira, a pesquisadora em questão traz categorias que têm o potencial de iluminar a realidade estudada. Vejamos um trecho de sua análise, realizada por meio de algumas categorias da Psicologia sociohistórica.

"Segundo Rey (2003, pp. 241-254), as emoções estão estreitamente ligadas às ações, por meio das quais caracterizam o sujeito no espaço de suas relações sociais. Para ele, a vivência da pessoa que é constituída historicamente gera um conjunto de emoções, que, por sua vez, geram necessidades. As necessidades são entendidas, aqui, como "estados produtores de sentido, associados à atuação do sujeito numa atividade concreta"; essas necessidades geram motivos que levam o sujeito a atuar de forma particular no mundo. Podemos, então, estabelecer relações entre as emoções vividas por Ferreira na fase em que se via e era vista como "incapaz", a entrada da religiosidade em sua vida e a sua forma atual de ação no mundo. "(o médico) [...] fez um tratamento comigo, me desintoxicou, me internou, tirou... todo o remédio, melhorou e me deu...ânimo. [...] 
O sentimento de exclusão, de inferioridade, de incapacidade, de ser doente, que ela deve ter vivido dos 14 aos 24 anos, geraram, para essa segunda fase de sua vida, a necessidade de ter sua capacidade e autonomia reconhecidas. "Aí comecei a ... a decidir minha vida, sozinha; a andar sozinha; viajar sozinha, trabalhar sozinha, sem que ninguém precisasse me levar. Eu comecei a fazer tudo sozinha aí... ao invés "d'eu" ser ajudada, eu comecei ajudar as pessoas."

A Doutrina Espírita - que foi sua salvação passa a ser parte constituinte de sua vida e os preceitos que norteiam essa Doutrina passam a nortear também suas ações e sua vida. Assim, ajudar, doar, abdicar e a caridade permeiam não só todo o discurso de Ferreira mas também sua ação/atividade" (pp.127128).

Podemos perceber, então, que a partir do momento em que Ferreira começa a 'viver uma nova vida', as múltiplas necessidades constituídas historicamente encontram novas formas possíveis de se configurar em motivos. Dessa maneira, diante de sua realidade profissional, ela passa a ajudar as pessoas, a doar seu tempo, a fazer caridade, a amar a todos como irmãos, a encontrar novos motivos que impulsionam sua vida.

\section{Vejamos:}

'[...] e assim, eu não cobro nada de ninguém, eu não peço nada pra ninguém, meu trabalho, meu trabalho é gratuito.'

A APAE entra, então, em sua vida, como uma benção,

[...] eu não estou trabalhando só prá me sustentar; eu estou trabalhando por prazer.[...]Eu estou trabalhando também por amor."

Segundo Agnes (pp.128-129), “...sentir-se útil a tira da esfera dos inválidos, incapazes. Ajudar as outras pessoas passa a ser uma necessidade pessoal e um motivo que a liga profissionalmente à atual instituição em que trabalha. Esse aspecto é tão forte que ela recusa o convite para trabalhar em uma outra atividade melhor remunerada.

Consideramos, nesse núcleo de significação, a caridade, a doação, a ajuda, o amor como elementos que, a partir da religiosidade, irão constituir os sentidos que serão atribuídos às experiências de vida de Ferreira.

É necessário ressaltar que as falas de Ferreira são reveladoras dos sentidos que se foram constituindo através das experiências vividas por ela, ou seja, os sentidos foram sendo construídos ao longo das suas experiências. Entretanto, esses sentidos, que são particulares, são, ao mesmo tempo, compostos pelos significados sociohistóricos da humanidade. Rey (2003, p. IX) nos ajuda a compreender esse caráter dialético da construção dos sentidos quando, ao tratar das questões referentes à produção dos sentidos e dos significados em Vigotski, afirma que :

"[.....] as criações humanas são produções de sentidos, que expressam de forma singular os complexos processos da realidade nos quais o homem está envolvido, mas sem constituir um reflexo destes. Em outras palavras, esses processos são uma criação humana, os quais, integrando os diferentes aspectos do mundo em que o sujeito vive, aparecem em cada sujeito ou espaço social concreto de forma única, organizados em seu caráter subjetivo pela história de seus protagonistas."

\section{"Ser normal ou estar deficiente: eis a questão!"}

Segundo Agnes (pp.130-131), um ponto importante para a análise refere-se à forma como, também inundada pelos princípios da religiosidade, Ferreira concebe a deficiência e o deficiente. Esse aspecto constitui, portanto, o segundo núcleo de significação. 
Como explicitado anteriormente, nesse núcleo de significação, foram agrupadas e articuladas as falas/conteúdos (indicadores) que se referem às concepções, sentimentos e práticas sobre deficiência e sobre a pessoa deficiente. Segundo a pesquisadora em questão (idem), ao ser solicitado a Ferreira que explicitasse sua forma de ver as pessoas com deficiência, ela parte do senso comum, de uma visão estereotipada dessas pessoas. Atribui a elas características tais como: "eles são dóceis", "carinhosos", "inteligentes", capazes", "não metem medo", "são bonzinhos", "gratos", "calmos". Percebe-se aqui que Ferreira apresenta uma visão ingênua, ideologizada, que descontextualiza o deficiente como ser historicamente situado, sendo essa uma visão que em nada contribui para a transformação das práticas educacionais, uma vez que se trata da educação de seres abstratos e idealizados. Retomando nossa intenção de exemplificar possíveis formas de se realizar uma análise, na perspectiva sociohistórica, vale destacar a importância de se buscar não apenas descrever os fatos, mas explicá-los, ou seja, buscar formas de explicitar a gênese social do individual. Agnes pretende, com sua análise, evidenciar que a fala da professora tem como elemento constitutivo, determinante, a ideologia, e o quanto esse tipo de visão (ideologizada) descontextualiza o problema, não contribuindo para a sua superação.

Voltando à análise realizada por Agnes (pp.130), ela afirma: "Interessante observar também que Ferreira, ao tentar apropriar-se dos 'discursos politicamente corretos' como aqueles que apregoam que somos todos iguais e, portanto, todos somos deficientes, ela incorre em uma contradição, pois, ao declarar a igualdade de todos, nega exatamente aquilo que nos singulariza - a diferença. Igualdade, normalidade, deficiência, direito, diferença, necessidades especiais são conceitos que ela parece não dominar, ou, no mínimo, são pouco elaborados".
'Olha, eu não vejo elas como deficientes não. Eu vejo elas como ser humano. Eu trato elas igual, eu não tenho esse negócio de que elas são coisa não. Na hora de cuidar delas a gente cuida... com mais carinho, cuida de... com um meio mais... adequado, mas olhar pra elas eu olho como ser humano. Como um irmão... igual! eu não olho elas como deficientes não. Porque deficientes somos todos, né?'

A idéia de que todos somos deficientes, de que todos temos uma deficiência, ou de que todos nós, em algum momento de nossas vidas, vivenciamos uma situação de "estar deficiente", foi muito difundida por Mantovan (1997) e Werneck (1999); entretanto, observa-se que muitos de nós, educadores, nos apropriamos dessa fala sem pensar nas implicações que ela traz. Mais uma vez, nega-se a diferença e, de uma forma simplista, reduzem-se as implicações político-pedagógicas, tais como: eliminação das barreiras programáticas e arquitetônicas, maior investimento em formação dos professores, etc., necessárias, por exemplo, para a alfabetização de uma criança cega ou surda. Concordamos com Sá (1992, p.14) quando afirma que a 'corrente máxima de que 'somos todos iguais' serve antes para ocultar o preconceito e justificar a exclusão do que para reconhecer a diferença'"

Nesse trecho da análise, destacamos a relevância do movimento empreendido pela pesquisadora, de não se contentar simplesmente em relatar a fala, mas em apreender as contradições presentes e buscar outras formas de se compreender o fenômeno. Ainda nesse trecho, evidencia-se a necessidade de o pesquisador conhecer as várias leituras da questão estudada, de conhecer a literatura sobre o tema para que possa realizar uma análise crítica, questionadora, que possa propiciar novas formas de se olhar os fenômenos.

Para se evidenciar a importância de uma compreensão mais completa da questão a ser 
'Então eu levo isso muito a sério, que eu sei que... que existe outra vida, e que eu já tive outras vidas passadas e vou ter outras, no futuro, então acho que... eu aceitando isso, esse princípio, então eu acho que todos aqueles que me procuram não me procuram por acaso não.' estudada, destacamos o esforço analítico realizado pela pesquisadora de inserir questões relativas a uma situação particular, num contexto mais amplo, considerando os aspectos sociais e políticos, inclusive articulando, em alguns momentos, os diferentes núcleos.

"Como apontado anteriormente, a religiosidade é marcante na vida de Ferreira. Da mesma forma que a sua vida é inundada pela Doutrina Espírita, também o é a concepção apresentada por ela sobre deficiência e sobre a pessoa deficiente. Entendemos tal concepção como naturalizante, ou seja, pouco ou nada analisa os aspectos sociohistóricos imbricados na constituição/construção da deficiência. Pelo contrário, para essa Doutrina, a deficiência e suas conseqüências estão ligadas a questões cármicas, isto é, a pecados ligados a vidas passadas. As pessoas deficientes teriam escolhido vir com deficiências nesta vida a fim de resgatar dívidas acumuladas em vidas passadas. A terra é considerada uma escola onde os espíritos, através da experiência, podem evoluir. Dessa forma, a questão da deficiência é abordada como se fosse a ordem natural das coisas. Ela acredita que cada um de seus alunos é deficiente porque tem algo de outra vida para resgatar, assim como também associa a sua "missão" na APAE como um resgate cármico.

'Então eu levo isso muito a sério, que eu sei que... que existe outra vida, e que eu já tive outras vidas passadas e vou ter outras, no futuro, então acho que... eu aceitando isso, esse princípio, então eu acho que todos aqueles que me procuram não me procuram por acaso não.'

Essa visão naturalizante corrobora com práticas assistencialistas e filantrópicas, mas é importante salientar que esse discurso assistencialista e caritativo não é exclusivo da Doutrina Espírita e de Ferreira. Ele está presente em nossa sociedade, evidenciandose principalmente na incipiente participação do poder público na gestão e financiamento da educação das pessoas com deficiência. Diante dessa falha ou, por que não dizer, diante do descaso do poder público, a educação do deficiente tem sido desempenhada quase que exclusivamente por entidades assistenciais e filantrópicas que, no dizer de Sá (1992, p.15), muitas vezes têm 'concepções autoritárias baseadas em sentimentalismos em que o deficiente é tratado como inferior, subalterno e infantil'" (pp.132).

Para finalizar as discussões sobre esse núcleo, apontamos ainda que os sentidos e significados acerca da deficiência e do deficiente, do modo como são apreendidos pela pesquisadora, aparecem como algo que faz parte da natureza humana e que são extremamente atravessados pela religiosidade, o que só pode ser globalmente apreendido também pela articulação dos núcleos entre si.

Concluindo nossas considerações sobre as análises realizadas por Célia e Agnes, afirmamos que, ao recorrerem a algumas das categorias analíticas e metodológicas da Psicologia sociohistórica, criaram as condições de ultrapassar a simples descrição dos dados, estabelecer relações que até então não haviam sido feitas, detectar a gênese de alguns fatos, afastar-se de explicações naturalizantes.

Importante ainda destacar que, para nos aproximarmos de uma apreensão mais global do sujeito, é necessária a articulação de todos os núcleos levantados. Em alguns casos, pela qualidade da informação obtida, num primeiro momento, a análise pode ficar mais circunscrita a aspectos da história do sujeito; entretanto, ao serem articulados com dados advindos da realidade social, cultural e com os outros núcleos, evidenciam-se outras determinações fundamentais, fazendo, inclusive, com que os dados adquiram outra qualidade. Acreditamos 
que, nesse movimento de articulação dos núcleos entre si, e com as condições sociais, históricas, ideológicas, condição de classe, gênero, e, sem dúvida, com os conhecimentos cientificamente produzidos sobre a área em questão, uma nova realidade surge, mais complexa, integrada, reveladora das contradições, movimento esse fundamental para a apreensão da constituição dos sentidos.

Temos a clareza, no entanto, da complexidade desse exercício de explicar, de como são múltiplas as determinações dos fatos. Desse modo, percebemos que, sem dúvida, outros determinantes poderiam ser contemplados nas explicações realizadas, mas que este é um momento do conhecimento atingido.

Como já afirmamos anteriormente, uma das marcas desse tipo de análise é ter como meta desvelar fatos e fenômenos, explicitar contradições e assim, ousar apontar caminhos mais críticos, menos naturalizantes e ideológicos .

\section{Anotações para análise de entrevista ${ }^{9}$}

\section{Pré-indicadores gerais}

sentimentos e emoções manifestados (felicidade, prazer, tristeza, solidão);

aceitação (ou não) pelos pais/parentes e por homens e mulheres (chavões ao exemplificar a relação gay x bandido, gay $x$ ladrão, etc.);

homossexualidade vista como legal;

sofrimento na relação com a escola;

- preconceito de alunos e de direção;

assumir para família (mesmo para quem rejeita? exemplifica apenas os que aceitam!!!!!!);

não assumir para outros;

aparência dos gays (masculino x feminino);

namoro (ficar);

ciúme, posse, fidelidade no namoro;

assumir para si / não assumir para o outro;

- não aceitação da homossexualidade da mãe (no início);

pai não existe para ele;

assumir-se determinando aceitar a mãe como homo;

respeito como determinante nas relações com os outros;

internet (pontos positivos e negativos);

internet e risco;

internet e cuidados;

- assumir e mudança na vida pessoal (positivamente);

o aceitar por parte de amigos;

amizade e balada;

amizade e diversão;

- amizade e apoio a situações de depressão;

amizade e "derrubar" (falsidade, inveja...);

amizade e idades dos amigos (funções diferentes);

- necessidade de gays serem unidos (não concretizada);

homossexualidade como alvo da violência;

- homossexualidade e gueto x outros lugares;

- assumir x estabilidade profissional ou econômica;

parada gay;

gay $\mathrm{x}$ heterossexual (iguais e normais);

normalidade (sentir-se normal);

amizade básica e fundamental para ele;

saúde e prevenção;

sexo seguro;
Anexo 1
9 Entrevista não utilizada na dissertação de mestrado de Elcio Nogueira dos Santos Conto ou não Conto? O Significado e os Sentidos de Tornar Pública a Orientação Sexual Homossexual para Adolescentes Masculinos da Cidade de São Paulo. Psicologia Social. Pucsp, 2004. 
a importância do assumir.

Indicadores resultantes da aglutinação dos pré-indicadores

visando à organização de núcleos

Emoções positivas ou negativas em relação ao homossexualismo

sentimentos e emoções manifestados (felicidade, prazer, tristeza, solidão);

homossexualidade vista como legal;

sofrimento na relação com a escola;

preconceito de alunos e de direção;

respeito como determinante nas relações com os outros;

- homossexualidade como alvo da violência;

amizade básica e fundamental para ele.

\section{Relações de amizade/união entre os homossexuais}

amizade e balada;

amizade e diversão;

amizade e apoio a situações de depressão;

amizade e "derrubar" (falsidade, inveja...);

amizade e idades dos amigos (funções diferentes);

necessidade de gays serem unidos (não concretizada);

homossexualidade e gueto x outros lugares;

gay $\mathrm{x}$ heterossexual (iguais e normais);

\section{Aceitação pelos outros da homossexualidade}

aceitação (ou não) pelos pais/parentes e por homens e mulheres (chavões ao exemplificar a relação gay x bandido, gay x ladrão, etc.);

não aceitação da homossexualidade da mãe (no início);

o aceitar por parte de amigos.

Assumir: para si, para os outros, para a família...

- assumir para a família (mesmo para quem rejeita? exemplifica apenas os que aceitam!!!!!!);

- não assumir para outros;

assumir para si / não assumir para o outro;

assumir-se determinando aceitar a mãe como homo;

- Assumir e mudança na vida pessoal (positivamente);

assumir x estabilidade profissional ou econômica;

normalidade (sentir-se normal);

a importância do assumir.

Outros: aparência / namoro e posse / internet / parada gay / saúde e prevenção...

aparência dos gays (masculino x feminino);

namoro (ficar);

ciúme, posse, fidelidade no namoro;

internet (pontos positivos e negativos);

internet e risco;

internet e cuidados;

parada gay;

saúde e prevenção;

sexo seguro. 
Wanda Maria Junqueira Aguiar

Professora titular da Faculdade de Psicologia e do Programa de Pós-Graduação em Psicologia da Educação da Pontifícia Universidade Católica de São PauloRua Bagé, 230/182 bloco C -

Vila Mariana 04012-140 São Paulo/SP

E-mail:iajunqueira@uol.com.br

Sergio Ozella

Professor associado da Faculdade de Psicologia e do Programa de Pós-Graduação em Psicologia Social da Pontifícia Universidade Católica de São Paulo. Rua Martiniano de Carvalho, 669/1101 - Bela Vista 01321-001 São Paulo/SP E-mail:ozella@uol.com.br

G. M. \& Furtado, O.(orgs). Psicologia Sociohistórica (uma Perspectiva Crítica em Psicologia).

São Paulo: Ed. Cortez, 2000, pp.129-140.

CALIL, Maria Izabel. A Constituição da Subjetividade em Menino de Rua. Análise de um Caso na Cidade de Santos. Mestrado em Psicologia Social. Pucsp. 2001,163 pp.

GONZALEZ REY, Fernando. La Investigación Cualitativa en Psicología: Rumbos y Desafios. São Paulo: Educ, 1999.

GONZÁLEZ REY, Fernando. Sujeito e Subjetividade - uma Aproximação Histórico-cultural. São Paulo: Ed. Thomson, 2003.

HELLER, Agnes.Teoria de los Sentimientos. Barcelona: Ed. Fontana, 1986.

LEITE, Lígia Costa. A Razão dos Invencíveis Meninos de Rua: o Rompimento da Ordem. 1554/1994. Rio de Janeiro: UFRJ/IPUB, 1998.

LUKACS, George. Estética: Categorias Básicas de lo Estético. Tomo 3. Barcelona-Mexico:Ed. Grijaldo, 1967.

MURTA, Agnes Maria Gomes. Contribuições da Psicologia Sociohistórica para a Educação Inclusiva: os Sentidos Produzidos por Professores da Educação Infantil de uma Cidade do Vale do Jequitinhonha acerca da Inclusão Escolar. Mestrado em Psicologia da Educação. Pucsp 2004, 173 pp.

NAMURA, Regina M. O Sentido do Sentido em Vygotsky : uma Aproximação com a Estética e a Ontologia do Ser Social. Tese de Doutorado em Psicologia Social.Pucsp, 2003, 209 pp.

NOVAES, Célia Ferreira. As Determinações Sociais no Problema da Escolha Profissional: Contradições e Angústias nas Opções dos Jovens das Classes Sociais de Alta Renda. Doutorado em Psicologia Social. Pucsp, 2003, 174 pp.

OLIVEIRA, B. A Dialética do Singular-Particular-Universal. Anais do V Encontro de Psicologia Social e Comunitária. Abrapso: Bauru, 